\title{
Multiple Sclerosis in Childhood: Report of 15 Cases
}

\author{
Folker Hanefeld, MD, Helmut J Bauer, MD, Hans-Jürgen Christen, MD, \\ Bernd Kruse, MD, Harald Bruhn, MD and Jens Frahm, MD
}

We report the preliminary results of an ongoing study of multiple sclerosis (MS) in childhood. The investigations include an analysis of the clinical picture and course. Multiple sclerosis in early childhood may present atypically, with a symptomatology suggesting diffuse encephalomyelitis, meningeal reaction, brain oedema, seizures, impaired consciousness and in some cases take a lethal course. Imaging studies including MRI and MR-spectroscopy, CSF-analysis, electrophysiology (VEP, BAEP, SER), and virological and immunological investigations are performed. So far 15 children have been studied. Their age at the onset of the disease ranged from 3 to 15 years. Abnormal CSF-findings with pleocytosis and oligoclonal IgG bands were present in 11 and 10 out of 15 patients respectively. MRI revealed numerous white matter lesions in the brain stem and cerebral hemispheres. VEP, BAEP and SER's were abnormal in most children. Proton magnetic resonance spectra from plaques exhibited a 50-80\% decrease in $N$-acetyl aspartate, which is a potential marker of vital neuronal tissue, a decrease of the creatine pool and an increase of choline-containing compounds. Lactate was not increased. Our observations of MS in early childhood cast doubt on some of the previous notions concerning a latency period of several years between the exposure to a still unknown agent and the manifestation of MS. In view of atypical features in the initial phase, it would seem desirable to record cases of encephalomyelitis of undetermined origin as potential cases of MS and to register the further course for verification or exclusion. Key words: Multiple sclerosis in childhood, clinical findings, MRI, MR-spectroscopy.

Hanefeld F, Bauer HJ, Christen H-J, Kruse B, Bruhn H, Frahm J. Multiple sclerosis in childhood: report of 15 cases.

Brain Dev 1991;13:410-6

The occurrence of multiple sclerosis (MS) in childhood is now well established [1-16]. Until 1980 one hundred thirty six patients with MS below the age of 18 years have been described. The disease started in 129 of those below the age of 18 years, in 20 of them before puberty. Since then the number of reported cases has steadily increased.

Over the ten year period from 1980 to 1990 a total of 235 cases has been published, 176 with onset before the age of 18 , in 43 patients before puberty (Table 1). There are now a number of well documented cases where the first symptoms of MS occurred before the age of 5 years

From the Department of Pediatrics and Child Neurology, Univercity Hospital (FH, HJB, HJC, BK); Max-Planck-Institut für Biophysikalische Chemie (HB, JF), Göttingen.

Received for publication: June 3, 1991.

Accepted for publication: June 3, 1991

Corresponding address: Prof. Folker Hanefeld, Department of Pediatrics and Child Neurology, University Hospital, D-3400, Göttingen, FRG.

\section{[17-22] (Table 2).}

Although the diagnosis of MS is in principle a clinical one, paraclinical investigations including MR-imaging, studies of evoked responses (visual evoked potentials (VEP), brain stem acoustic evoked potentials (BAEP), somatosensory evoked responses (SER)) and of immunoglobulins of CSF have proved extremely valuable in the identification and monitoring of demyelinating disorders in childhood. Particularly the non-invasive magnetic resonance imaging (MRI) shows a high sensibility in detecting white-matter abnormalities in children with MS [23-26].

We report the results of an ongoing prospective study of childhood MS.

\section{MATERIALS AND METHODS}

Fifteen patients, 11 female and 4 male children have been studied so far. Their age at onset of the disease ranged from 3 to 15 years (Fig 1). They were further divided into a prepubertal and an adolescent group (Table 1). Cranial 
Table 1 Multiple sclerosis in childhood

\begin{tabular}{lcc} 
& \multicolumn{2}{c}{ Age at onset } \\
& Prepuberty & Adolescence \\
\hline $\begin{array}{l}\text { Studies bef. } 1980 \\
(\mathrm{n}=136)\end{array}$ & $20 / 129^{+}$ & $109 / 129^{++}$ \\
$\begin{array}{l}\text { Studies since } 1980 \\
(\mathrm{n}=235)\end{array}$ & $43 / 176^{+}$ & $133 / 176^{++}$ \\
$\begin{array}{l}\text { Göttingen study } \\
(\mathrm{n}=15)\end{array}$ & $12 / 15^{+}$ & $3 / 15^{+++}$ \\
\hline
\end{tabular}

$+:<12$ years, $++:<18$ years, $++t<<15$ years.

Table 2 Multiple sclerosis in childhood: Patients with earliest onset of $M S$

\begin{tabular}{llc}
\hline & & $\begin{array}{c}\text { Earliest age } \\
\text { of onset (yrs) }\end{array}$ \\
\hline 1990 & Bauer, Hanefeld, Christen [22] & 3 \\
1984 & Bejar, Ziegler [18] & 2 \\
1988 & Boutin et al [14] & 2 \\
1981 & Brandt et al [17] & 2 \\
1985 & Bye et al [6] & 3 \\
1987 & Golden, Woody [23] & 3 \\
1987 & Haas et al [24] & $41 / 2$ \\
1982 & Hauser et al [5] & 3 \\
1984 & Ishihara et al [36] & 5 \\
1989 & Kesselring et al [26] & 2 \\
1989 & Maeda et al [20] & $1 / 2$ \\
1988 & Mattyus, Veres [16] & 4 \\
1990 & Miller et al [11] & 2 \\
1969 & Schneider et al [46] & 4 \\
1987 & Shaw, Alvord [21] & $21 / 4$ \\
1988 & Vergani et al [47] & 2 \\
\hline
\end{tabular}

computerized tomography (CCT), MRI, localized proton MR-spectroscopy (MRS), electrophysiological examinations (VEP, BAEP, SER) and CSF analysis were performed in all patients. Localized proton MRS was performed using a stimulated echo aquisition mode (STEAM) sequence with an echo time of $20 \mathrm{~ms}$ yielding spectra from $1-12 \mathrm{ml}$ volumes of interest (VOI) within 5-10 min. All studies were performed at 2.0-T (Siemens Magnetom) using the regular imaging head coil for both MRI and MRS [27].

The patients were classified as definite, probable and possible cases according to the criteria of the IMABenquete [28-31].

\section{RESULTS}

The results of our study are shown in detail in Table 3 and summarized in Table 4 . Out of the 15 children five were
Multiple Sclerosis in Childhood Age at Onset

number of pat.

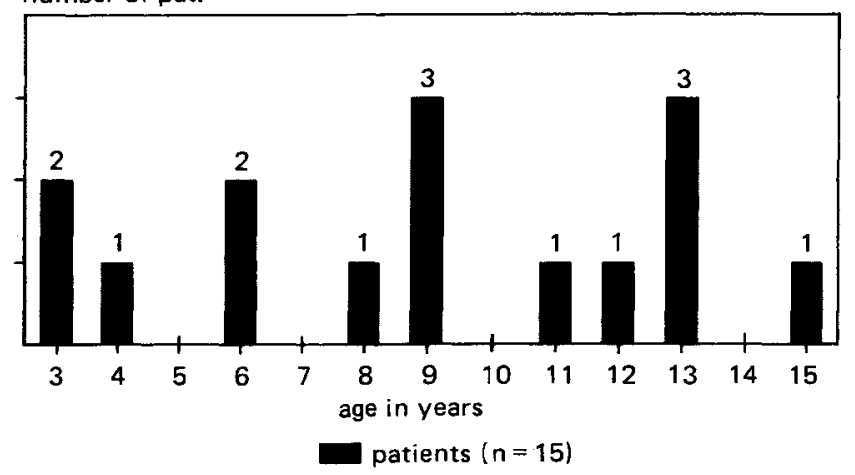

Fig 1 Multiple sclerosis in childhood: 15 patients of Göttingenstudy.

\section{Multiple Sclerosis in Childhood Distribution of Cardinal Symptoms}

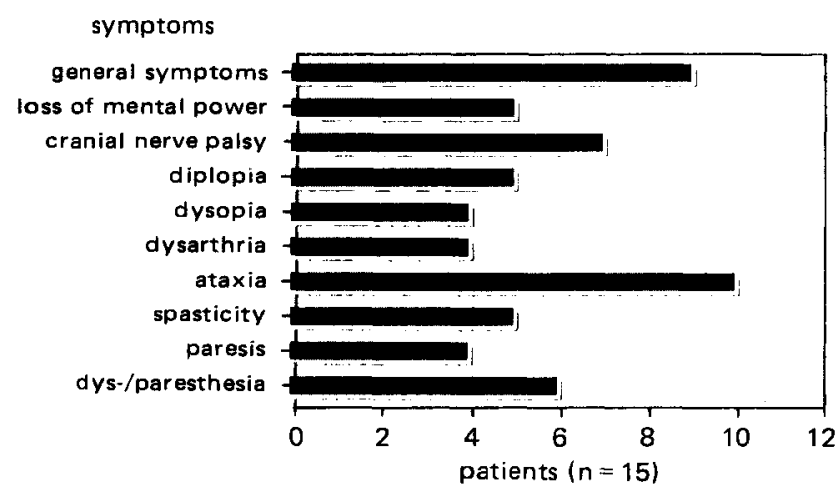

Fig 2 Multiple sclerosis in childhood: Distribution of cardinal symptoms.

classified as probable and two as possible cases of MS. In eight children a definite diagnosis of MS could be established, including our youngest patient (case 6) in whom the disease started before the age of 4 years.

The age at onset ranged from 3 to 15 years, with a sex ratio (female: male) of 3:1. First symptoms occured in 12 children ( 9 girls, 3 boys) before puberty; in 3 children ( 2 girls, 1 boy) they started in adolescence. Initial symptoms ranged from school problems, paresthesias and transient visual disturbances to rather dramatic clinical presentations, suggesting diffuse encephalopathy with cerebral oedema, meningeal reactions, nerve palsies and impaired consciousness. Seizures were not observed (Fig 2).

Later on a variety of symptoms developed and persisted. 11 of the children now show persistent neurological symptoms with a Kurtzke scale (EDSS) from 1.5 to 7.0 [32]. The CSF showed a pleocytosis (5-50 cells/ 
Table 3 Multiple sclerosis in childhood: Data of 15 patients of Göttingen-study

\begin{tabular}{|c|c|c|c|c|c|}
\hline Case number, sex & 1. $F$ & 2. $F$ & 3. $F$ & 4. $M$ & 5. $M$ \\
\hline History & $\mathbf{N}$ & N VI-palsy & $\begin{array}{l}\text { Nystagmus, } \\
\text { bronchial asthma }\end{array}$ & $\begin{array}{l}\text { Tonsillectomy, } \\
\text { infect. mononucleosis }\end{array}$ & $\begin{array}{l}\text { Adenoidectomy, } \\
\text { allerg. diathesis }\end{array}$ \\
\hline Vaccinations & DPT, polio & $?$ & $?$ & $\begin{array}{l}\text { Measles, mumps, } \\
\text { BCG, polio, DPT }\end{array}$ & $\begin{array}{l}\text { Polio, tetanus, } \\
\text { BCG, diphtheria }\end{array}$ \\
\hline Age at onset (yrs) & 9 & $111 / 2$ & 15 & $131 / 2$ & $91 / 2$ \\
\hline Main neurol. symptoms & $\begin{array}{l}\text { Charcot triad, } \\
\text { ataxia, } \\
\text { spastic paraplegia }\end{array}$ & $\begin{array}{l}\text { N VII-palsy, } \\
\text { encephalopathy, } \\
\text { paresis right leg, } \\
\text { paresthesia }\end{array}$ & $\begin{array}{l}\text { Visual disturbances, } \\
\text { head retraction }\end{array}$ & $\begin{array}{l}\text { Cranial nerve palsy, } \\
\text { motor-sensory } \\
\text { hemiplegia }\end{array}$ & $\begin{array}{l}\text { N, VI/VII-palsy, } \\
\text { spastic paraplegia }\end{array}$ \\
\hline $\begin{array}{ll}\text { CSF } & \text { cells } / \mathrm{mm}^{3} \\
& \text { protein }(\mathrm{mg} \%) \\
& \text { Ig G } \\
& \text { oligoclonal bands }\end{array}$ & $\begin{array}{l}15 \\
41 \\
\text { autoch thonous } \\
+\end{array}$ & $\begin{array}{l}20 \\
59 \\
\text { autochthonous } \\
+\end{array}$ & $\begin{array}{l}17 \\
54 \\
\text { autochthonous } \\
+\end{array}$ & $\begin{array}{l}8 \\
24 \\
\text { autochthonous } \\
+\end{array}$ & $\begin{array}{l}30 \\
42 \\
\text { autoch thonous } \\
+\end{array}$ \\
\hline VEP & $\mathbf{P}$ & $\mathbf{P}$ & Not valuable & $\mathbf{P}$ & $\mathbf{P}$ \\
\hline BAEP & $\mathrm{P}$ & $\mathbf{P}$ & $\mathbf{P}$ & $\mathbf{P}$ & $\mathbf{P}$ \\
\hline CCT & Hypodensities & Hypodensities & $\mathbf{N}$ & $\mathbf{N}$ & $\mathbf{N}$ \\
\hline MRI & ML & ML & ML & ML & ML \\
\hline Therapy & $\begin{array}{l}\text { Cortisone, } \\
\text { azathloprine, } \\
\text { cyclophosphamide }\end{array}$ & Cortisone & Cortisone & - & $\begin{array}{l}\text { Cortisone, } \\
\text { azathloprine }\end{array}$ \\
\hline Course & Chronic progressive & Intermittent & Chronic & Intermittent & Intermittent \\
\hline Diagnosis & Definite & Definite & Definite & Definite & Definite \\
\hline Case number, sex & 6. $M$ & 7. $F$ & 8. $F$ & 9. $F$ & 10. $F$ \\
\hline History & $\begin{array}{l}\text { Cesarian section, } \\
\text { hypotonia measles }\end{array}$ & $\begin{array}{l}\text { Infect. mono- } \\
\text { nucleosis }\end{array}$ & $\mathrm{N}$ & $\mathbf{N}$ & $\mathbf{N}$ \\
\hline Vaccinations & $\begin{array}{l}\text { DPT, polio, } \\
\text { mumps }\end{array}$ & $\begin{array}{l}\text { DPT, BCG, polio, } \\
\text { measles }\end{array}$ & 7 & $\begin{array}{l}\text { DPT, polio, } \\
\text { measles, BCG }\end{array}$ & $\begin{array}{l}\text { BCG, DPT, } \\
\text { measles }\end{array}$ \\
\hline Age at onset (y rs) & 3 & $131 / 2$ & $31 / 2$ & 13 & $61 / 2$ \\
\hline Main neurol. symptoms & $\begin{array}{l}\text { Nystagmus, } \\
\text { ataxia }\end{array}$ & $\begin{array}{l}\text { N VII-palsy, } \\
\text { motor-sensory } \\
\text { hemiplegia, } \\
\text { ataxia }\end{array}$ & $\begin{array}{l}\text { Nystagmus, } \\
\text { optic atrophy, } \\
\text { ataxia }\end{array}$ & $\begin{array}{l}\text { Diplopia, } \\
\text { N VI-, VII-, XII-palsy, } \\
\text { a taxia }\end{array}$ & $\begin{array}{l}\text { Nausea, } \\
\text { diplopia, } \\
\text { dysarthria, } \\
\text { ataxia }\end{array}$ \\
\hline $\begin{array}{ll}\mathrm{CSF} & \text { cells } / \mathrm{mm}^{3} \\
& \text { protein }(\mathrm{mg} \%) \\
& \mathrm{IgG} \\
& \text { oligoclonal bands }\end{array}$ & $\begin{array}{l}1 \\
16 \\
\text { autochthonous } \\
+\end{array}$ & $\begin{array}{l}1 \\
41 \\
\text { autochthonous } \\
+\end{array}$ & $\begin{array}{l}60 \\
86 \\
\text { autochthonous } \\
-\end{array}$ & $\begin{array}{l}\text { Pleocytosis } \\
46 \\
\text { autochthonous } \\
+\end{array}$ & $\begin{array}{l}18 \\
108 \\
\text { autochthonous } \\
-\end{array}$ \\
\hline VEP & $P$ & $\mathbf{N}$ & $\mathrm{N}$ & $\mathbf{P}$ & $\mathbf{N}$ \\
\hline BAEP & $\mathbf{P}$ & $\mathrm{N}$ & $\mathbf{P}$ & $N$ & $\mathbf{P}$ \\
\hline $\mathrm{CCT}$ & $\mathrm{N}$ & Hypodensities & $\mathrm{N}$ & Hypodensities & Hypodensities \\
\hline MRI & ML & ML & $\mathrm{N}$ & $\mathrm{ML}$ & ML \\
\hline Therapy & - & $\begin{array}{l}\text { Cortisone } \\
\text { azathioprine }\end{array}$ & Dexamethasone & $\begin{array}{l}\text { Cortisone } \\
\text { dexamethasone }\end{array}$ & - \\
\hline Course & Intermittent & Intermittent & Intermittent & Intermittent & 1 attack only \\
\hline Diagnosis & Definite & Probable & Probable & Definite & Probable \\
\hline
\end{tabular}

F: female, M: male, ML: multiple lesions, N: normal, P: pathological. 
(continued)

\begin{tabular}{|c|c|c|c|c|c|}
\hline Case number, sex & 11. $M$ & 12. $F$ & 13. $F$ & 14. $F$ & 15. $F$ \\
\hline History & $\mathbf{N}$ & $\mathbf{N}$ & $\mathbf{N}$ & Strabismus converg. & Allerg. diathesis \\
\hline Vaccinations & $?$ & $\begin{array}{l}\text { DPT, } \\
\text { rubella }\end{array}$ & $?$ & $\begin{array}{l}\text { Measles, mumps, } \\
\text { rubella, diphtheria } \\
\text { BCG, polio, tetanus }\end{array}$ & $?$ \\
\hline Age at onset (yrs) & $49 / 12$ & $121 / 2$ & 6 & 9 & $81 / 2$ \\
\hline Main neurol. symptoms & $\begin{array}{l}\text { N VI-palsy, } \\
\text { anisocoria, } \\
\text { meningism, } \\
\text { a taxia }\end{array}$ & $\begin{array}{l}\text { Headache, } \\
3 \text { episodes of } \\
\text { hemiparesthesia }\end{array}$ & $\begin{array}{l}\text { Facial tic, } \\
\text { dementia }\end{array}$ & $\begin{array}{l}\text { Ataxic gait } \\
\text { urinary urgency } \\
\text { incontinence }\end{array}$ & $\begin{array}{l}\text { Visual disturbances, } \\
\text { ataxia, } \\
\text { spastic paraplegia, } \\
\text { par-/dysesthesia }\end{array}$ \\
\hline $\begin{array}{ll}\mathrm{CSF} & \text { cells } / \mathrm{mm}^{3} \\
& \text { protein (mg \%) } \\
\mathrm{IgG} \\
\text { oligoclonal bands }\end{array}$ & $\begin{array}{l}27 \\
42 \\
N \\
-\end{array}$ & $\begin{array}{l}16 \\
71 \\
\text { autochthonous } \\
+\end{array}$ & $\begin{array}{l}1 \\
17 \\
+\end{array}$ & $\begin{array}{l}1 \\
20 \\
11 \mathrm{mg} / \mathrm{dl} \\
-\end{array}$ & + \\
\hline VEP & $\mathbf{P}$ & $\mathbf{P}$ & $\mathbf{N}$ & $\mathbf{P}$ & $\mathbf{P}$ \\
\hline BAEP & $\mathbf{P}$ & $\mathbf{P}$ & $\mathbf{N}$ & $\mathbf{P}$ & Not valuable \\
\hline $\mathrm{CCT}$ & $?$ & $\mathbf{N}$ & - & - & $\mathbf{N}$ \\
\hline MRI & ML & Small lesions (?) & ML & ML & ML \\
\hline Therapy & - & - & - & - & Dexamethasone \\
\hline Course & $?$ & $\begin{array}{l}3 \text { relapses } \\
\text { compl. remission }\end{array}$ & Chronic & Chronic & Intermittent \\
\hline Diagnosis & Probable & Probable & Possible & Possible & Definite \\
\hline
\end{tabular}

F: female, M: male, ML: multiple lesions, N: normal, P: pathological.

Table 4 Multiple sclerosis in childhood: Summarized results of Göttingen-study

$\begin{array}{lcc}\begin{array}{l}\text { Number of pat. } \\ \text { Definite MS: } 8,\end{array} & \text { Probable MS: } 5, \text { Possible MS: } 2 \\ \text { Age at onset: } & 3-15 \text { yts. } \\ \text { Paraclinical results: } & \text { CSF: Pleocytosis } & 11 \text { pat. } \\ & \text { Increased prot. } & 10 \text { pat. } \\ & \text { Oligocl. bd. } & 10 \text { pat. } \\ & \text { Pathol. VEP: } & 9 \text { pat. } \\ & \text { Pathol. AEP: } & 11 \text { pat. } \\ & \text { Pathol. CCT: } & 5 \text { pat. } \\ & \text { Pathol. MRI: } & 14 \text { pat. } \\ & \text { Pathol. MRS: } & 12 \text { pat. }\end{array}$

MS: Study Göttingen 05.91 .

$\mathrm{mm}^{3}$ ), increased levels of $\operatorname{IgG}$ and oligoclonal bands in all definite cases.

Evoked responses (VEP and/or BAEP) were abnormal in all definite cases. MRI studies of the brain proved to be the most sensitive method in detecting cerebral whitematter abnormalities. Asymmetrical multifocal and periventricular white-matter lesions were observed in both cerebral hemispheres, the cerebellum and brain stem (Fig

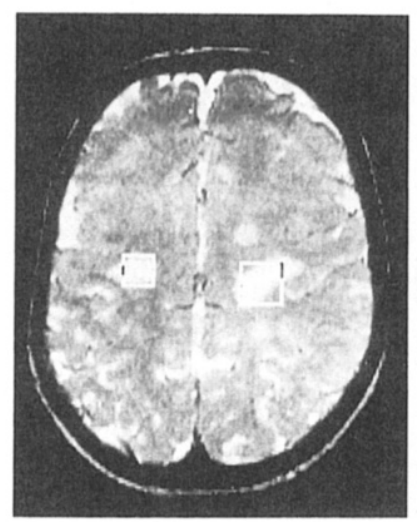

Fig 3 Case no 6, age: $71 / 2$ yrs, MRI.

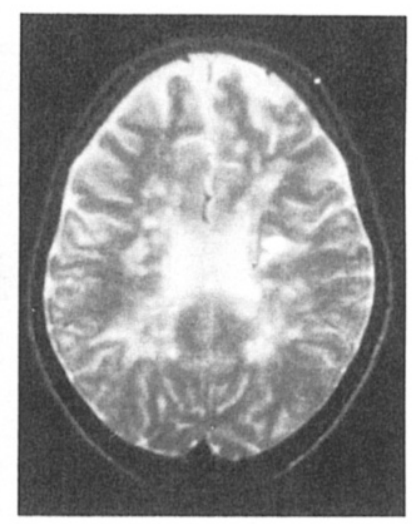

Fig 4 Case no 1, age: 15 yrs, MRI.
3,4). The CCT of one patient (case 2) initially showed multiple ring-like structures resembling a cerebral abscess (Fig 5). MR spectroscopy, performed in 14 patients, showed a $50-80 \%$ decrease of $\mathrm{N}$-acetyl aspartate (NAA) which is a marker for vital neuronal tissue, a similar decrease of the creatine pool, an increase of choline-containing compounds, and, more discretely, an increase of the inositols in the lesions. Lactate was not increased. Adjacent white matter showed similar results as normal 
controls, cortical gray matter related to neighboring multiple sclerosis lesions showed a reduction of $\mathrm{N}$-acetylaspartate (Fig 6a, 6b).

Longitudinal studies in 3 patients revealed a consistent pattern of the plaques (detailed publication in preparation).

Most patients were treated with steroids during the acute phase, some received azathioprine, one cyclophosphamide with the same conflicting results as known from adult patients.

\section{DISCUSSION}

Our data from 15 patients confirm earlier publications on childhood multiple sclerosis: it is a rare but existent disease in childhood. Its frequency is approximately $0.3 \%$ to $2 \%$ of all cases of MS [8, 33]. There are now 24 children known in whom the disease started before the age of five years (Table 2).

The female preponderance reported by others [8] was also evident in our prepubertal (juvenile) group. Although the symptomatology of childhood MS shows no qualitative differences to adult patients, some atypical presentations have to be mentioned. Multiple sclerosis in early childhood more frequently shows acute symptoms suggesting diffuse encephalomyelitis [34, 35], or even a cerebral abscess or an acute metabolic encephalopathy $[16,36]$.

An analysis of 71 cases showed a lethality of $10 \%$ during the first 5 years of the disease in children compared to 0 in 800 adult patients [12]. These peculiarities of childhood MS might be due to the increased vulnerability of the developing brain and the immaturity of the immune system in children.

From our data no conclusions can be drawn with respect to early childhood infections, vaccination or inheritance [37].

A history of optic neurits was not noticed in any of our patients. This is probably due to the small number of cases, since several publications describe the development of MS in up to $10 \%$ of all children who suffered from optic neurits [38-42].

As in other publications the MRI proved to be the most sensitive method for the diagnosis as well as for follow-up studies. However it must be pointed out that its specificity is low. The introduction of gadolinium to a certain extent makes a distinction of acute and chronic lesions possible [43].

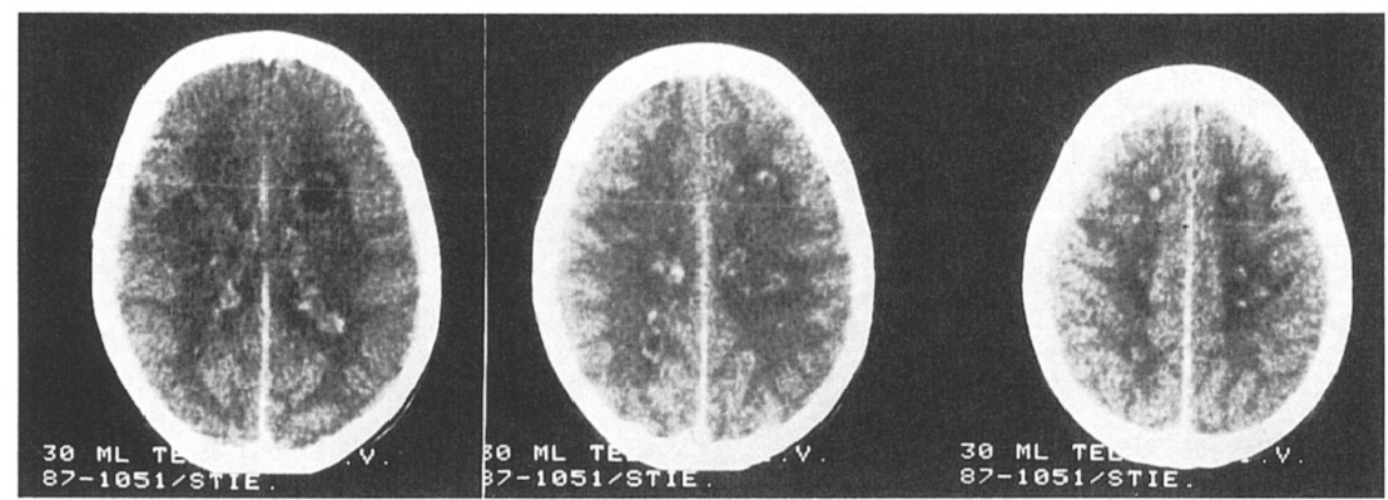

NAA

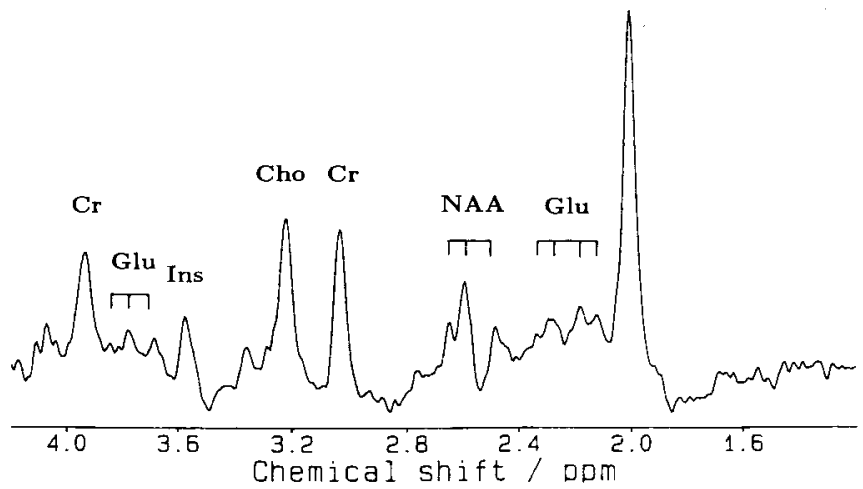

Fig 6a: Normal control, age: $121 / 2$ yrs, MRS TR 3000 AC 128 TE $2012 \mathrm{ml}$.

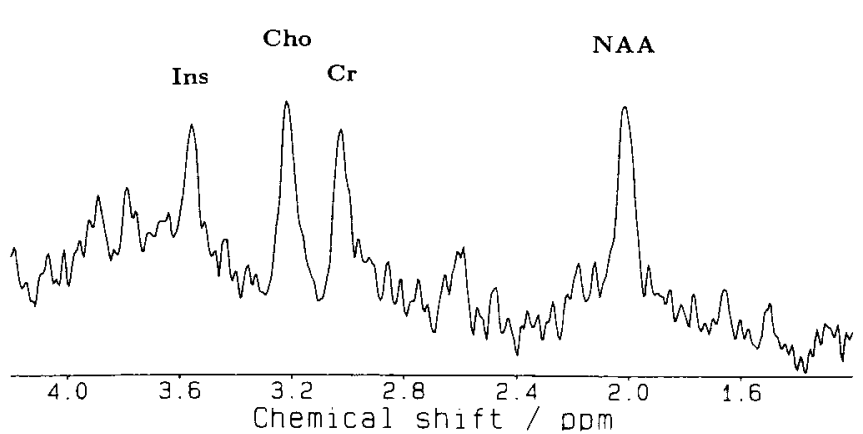

Fig 6b: Case no 2, age: 14/12 yrs, MRS TR 3000 AC 128 TE 20 $4 \mathrm{ml}$. 
Thus far MR spectroscopy has not been performed in MS in children. The findings are similar to results reported in single adult patients [44]. This method is very promising and will probably provide more insight into the metabolic events during inflammatory demyelination, about the progress of the disease and the value of treatment modalities.

The hypothesis has been widely accepted that MS is an autoimmune disease following the exposition to a transmissible agent, possibly a virus, before puberty. Presumably due to the persistence of a virus or of virus fragments, an autoimmune reaction against myelin basic protein or some other component of myelin, a latency ("incubation") period of some years is believed to elapse before the manifestation of MS later in life. Under the assumption of a "point source" epidemic in the Faroe islands an interval of 6 years or more between the exposure to a transmissible agent and the appearance of clinical symptoms was calculated [45]. The fact that MS can occur in early childhood (before the age of 3 years) casts some doubts on this hypothesis. Furthermore due to the application of rigid criteria (onset from 10 to 50 years) childhood MS has been largely neglected in research on this disease in the past. From the data available in literature and reported here it seems necessary to classify patients with early onset of the disease as infantile/ juvenile form of MS. Unquestionable, strict definitions are an essential prerequisite for reliable information on childhood MS.

In view of atypical features in the initial phase, it would also seem desirable to record cases of encephalomyelitis of undetermined origin as potential cases of MS and to register the further course for verification or exclusion.

Essential features in the chain of immunopathological events leading to demyelination in MS have been demonstrated in animal models of experimental demyelination and have served as leads for directing immunological research in MS. In the variable, undulating and chronicprogressive course of MS in the adult, it is very difficult to show that the pathogenicity in the human disease is the same as in experimental models. In childhood MS an earlier and more rapid sequence of pathogenetic events pinpoint the way to some unsolved questions.

\section{ACKNOWLEDGMENTS}

Financial support by the Bundesminister für Forschung und Technologie (BMFT) of the Federal Republic of Germany (Grant 01 VF 8606/6) and the Hertie-Stiftung (GHS $155 / 88$ ) is gratefully acknowledged.

\section{REFERENCES}

1. Carter HR. Multiple sclerosis in childhood. Am J Dis Child 1946; $71: 138-49$.
2. Gall JC, Hayles AB, Siekert RG, Keith HM. Multiple sclerosis in children. Pediatrics 1958;21:703-9.

3. Isler W. Multiple Sklerose im Kindesalter. Helv Paediatr Acta $1961 ; 16: 412-31$.

4. Andler W, Roosen K. Multiple Sklerose im ersten Lebensjahrzehnt. Klin Pädiatr 1980; 192:365-9.

5. Hauser SL, Bresnan MJ, Reinherz EL, Weiner HL. Childhood multiple sclerosis: clinical features and demonstration of changes in T cell subsets with disease activity. Ann Neurol $1982 ; 11: 463-8$.

6. Bye AME, Kendall B, Wilson J. Multiple sclerosis in childhood. A new look. Dev Med Child Neurol 1985; 27:215-22.

7. Izquierdo G, Lyon-Caen O, Marteau R, et al. Early onset multiple sclerosis. Clinical study of 12 pathologically proven cases. Acta Neurol Scand 1986; $73: 493-7$.

8. Duquette P, Murray TJ, Pleines J, et al. Multiple sclerosis in childhood: clinical profile in 125 patients. $J$ Pediatr 1987; 111:359-63.

9. Morimoto $T$, Nagao $H$, Sano $N$, et al. A case of multiple sclerosis with multi-ring-like and butterfly-like enhancement on computerized tomography. Brain Dev (Tokyo) 1985; 7: 43-5.

10. Greger G, Emmrich P, Staudt F, Czettritz G. Encephalomyelitis disseminata, ED (Multiple Sklerose, MS) im Kindesund Jugendalter. Pädiatr Prax 1989/90; 39:473-86.

11. Miller DH, Robb SA, Ormerod IEC, et al. Magnetic resonance imaging of inflammatory and demyelinating white-matter diseases of childhood. Dev Med Child Neurol 1990;32: 97-107.

12. Bauer HJ, Hanefeld F. Multiple Sklerose im Kindesalter. In: Hanefeld F, Rating D, Christen HJ, eds. Aktuelle Neuropädiatrie 1989. Berlin: Springer-Verlag 1990:285-98.

13. Baier WK. Multiple Sklerose im Kindesalter. Literaturübersicht und eigene Beobachtungen. In: Fichsel $\mathrm{H}$, ed. Aktuelle Neuropädiatrie 1986. Berlin: Springer-Verlag 1987:72-9.

14. Boutin B, Esquivel E, Mayer M, Chaumet S, Ponsot G, Arthuis M. Multiple sclerosis in children: report of clinical and paraclinical features of 19 cases. Neuropediatrics 1988; 19:118-23.

15. Sheremata W, Brown SB, Curless RR, Dunn HG. Childhood multiple sclerosis: a report of 12 cases. Ann Neurol 1981; 10:304.

16. Mattyus A, Veres E. Multiple sclerosis in childhood: long term katamnestic investigations. Acto Paediatr Hung 1985; 26:193-204.

17. Brandt S, Gyldensted C, Offner H, Melchior JC. Multiple sclerosis with onset in a two-year-old boy. Neuropediatrics $1981 ; 12: 75-82$.

18. Bejar JM, Ziegler DK. Onset of multiple sclerosis in a 24 month-old child. Arch Neurol 1984;41:881-2.

19. DiMario FJ, Bermann PH. Multiple sclerosis presenting at 4 years of age: clinical and MRI correlations. Clin Pediatr 1987; 27:32-7.

20. Maeda Y, Kitamoto I, Kurokawa T, Ueda K, Hasuo K, Fujioka K. Infantile multiple sclerosis with extensive white matter lesions. Pediatr Neurol 1989; 5:317-9.

21. Shaw CM, Alvord ES. Multiple sclerosis beginning in infancy. J Child Neurol 1987; 2:252-6.

22. Bauer HJ, Hanefeld F, Christen HJ. Multiple sclerosis in early childhood. Lancet 1990; 336:1190.

23. Golden GS, Woody RC. The role of nuclear magnetic resonance imaging in the diagnosis of MS in childhood. $J$ Neurol 1987; 37:689-93.

24. Haas G, Schroth G, Krageloh-Mann I, Buchwald-Saal M. Magnetic resonance imaging of the brain of children with multiple sclerosis. Dev Med Child Neurol 1987;29:586-91. 
25. Millner MM, Ebner F, Justich E, Urban C. Multiple sclerosis in childhood: contribution of serial MRI to earlier diagnosis. Dev Med Clin Neurol 1990; 32:769-77.

26. Kesselring J, Ormerod IEC, Miller DH, du Boulay EPGH, McDonald WI. Magnetic resonance imaging in multiple sclerosis. Stuttgart-New York: Thieme-Verlag, 1989.

27. Bruhn H, Frahm J, Merboldt KD, et al. Metabolic alterations in children with multiple sclerosis as detected by localized proton MRS. New York: Society of Magnetic Resonance in Medicine, 1990; 90:163-90.

28. Poser CM, Paty DW, Scheinberg L, et al. New diagnostic criteria for multiple sclerosis: guidelines for research protocols. Ann Neurol 1983; 13:227-31.

29. Poser CM. A numerical scoring system for the classification of multiple sclerosis. Acta Neurol Scand 1979;60:100-11.

30. Schumacher GA, Beebe G, Kibler RF, et al. Problems of experimental trials of therapy in multiple sclerosis. Ann $N Y$ Acad Sci 1965;122:552-68.

31. Bauer HJ. IMAB-enquete concerning the diagnostic criteria for MS. In: Bauer HJ, ed. Progress in multiple sclerosis research. Berlin: Springer Verlag, 1980:555-63.

32. Kurtzke JF. Rating neurologic impairment in multiple sclerosis: an expanded disability status scale (EDSS). Neurology (Cleveland) 1983;33:1444-52.

33. Lowis GW. The social epidemiology of multiple sclerosis. Sci Total Environ 1990; 90:163-90.

34. Kesselring J, Miller DH, Robb SA, et al. Acute disseminated encephalomyelitis. Brain 1990;113:291-302.

35. Johnsen SD, Sidell AD, Bird CR. Subtle encephalomyelitis in children: a variant of acute disseminated encephalomyelitis. $J$ Child Neurol 1989;4:213-6.

36. Ishihara $\mathrm{O}$, Yamaguchi $\mathrm{Y}$, Matsuishi $\mathrm{T}$, et al. Multiple ring enhancement in a case of acute multiple sclerosis. Brain Dev
(Tokyo) 1984;6:401-6.

37. Sadovnick AD, Bulman D, Ebers GC. Parent-child concordance in multiple sclerosis. Ann Neurol 1991;29:252-5.

38. Kennedy C, Carter S. Relation of optic neuritis to multiple sclerosis in children. Pediatrics 1961;28:377-87.

39. Haller P, Patzold U. Die Optikusneuritis im Kindesalter. Fortschr Neurol 1979;47:209-16.

40. Parkin PJ, Hierons R, McDonald WI. Bilateral optic neuritis. Brain 1984; 107:951-64.

41. Riikonen R, Ketonen L, Sipponen J. Magnetic resonance imaging, evoked responses and cerebrospinal fluid findings in a follow-up study of children with optic neuritis. Acta Neurol Scand 1988; 77:44-9.

42. Riikonen R, Donner M, Erkkilä H. Optic neuritis in children and its relationship to multiple sclerosis: a clinical study of 21 children. Dev Med Child Neurol 1988; 30:349-59.

43. Harris JO, Frank JA, Patronas N, McFarlin DE, McFarland HF. Serial gadolinium-enhanced magnetic resonance imaging scans in patients with early, relapsing-remitting multiple sclerosis: implications for clinical trials and natural history. Ann Neurol 1991;29:548-55.

44. Miller DH, Austin SJ, Connelly A, Youl BD, Gadian DG, McDonald WI. Proton magnetic resonance spectroscopy of an acute and chronic lesion in multiple sclerosis. Lancet 1991; 337:58-9.

45. Kurtzke JF, Hyllestedt K. Multiple sclerosis in the Faroe Islands. Neurology 1986;36:307-28

46. Schneider RD, Ong BH, Moran MJ, Greenhouse AH. Multiple sclerosis in early childhood. Clin Pediatr 1969;8:115-8.

47. Vergani MIC, Reimao R, Camara Silva AM, Muskat M, Esposito S, Diament A. Multiple sclerosis with early childhood onset. Arq Neuro-Psiquiat (Sao Paulo) 1988;46:195-7. 